\title{
Contribution of Cooperative Principle to the Interpretation of Irony*
}

\author{
Qin Yao \\ School of Foreign Languages, Jiangsu University, Zhenjiang, Jiangsu, China \\ Email: yaoqinz@qq.com
}

\begin{abstract}
Through gathering, analyzing and evaluating some cases of irony from Three Kingdoms by Luo Guanzhong and its translator Roberts, this paper aims to bring the issue of the significance of the indispensability of resorting to Grice's (1975) cooperative principle (CP) for the analysis of irony in the interpretation of utterances.
\end{abstract}

Index Terms - cooperative principle, utterances from Three Kingdoms, irony

\section{THEORETICAL BACKGROUND}

Irony, in the restricted sense, a form of linguistic ambiguity, has become a well-established colorful form of writing in the literature. Writers use irony to achieve their rhetorical ends-be they comic, moral, corrective and/or hortatorythrough textual, grammatical, lexical manipulation. Booth classifies irony in two forms: stable and unstable; each is divided into local and infinite on two levels: covert and overt (1974:235). Stable irony involves two steps: the authors offer an unequivocal invitation to reconstruct and this reconstruction is not to be later undermined (1974:233). Unstable irony, on the other hand, implies that "no stable reconstruction can be made out of the ruins revealed through the irony."(1974:240) Muecke (1982) differentiates between two classes of irony: observable irony and instrumental irony. Instrumental irony is used when someone realizes a purpose using language ironically, while observable irony could be unintentional and hence representable in art. Muecke (1969) distinguishes four modes of irony: impersonal, self-disparaging, ingenuous and dramatized, and gives impersonal irony the most prominent place and classification. Impersonal irony includes: praising in order to blame; blaming in order to praise, pretended agreement with the victim of irony; pretended advice or encouragement to the victim; the rhetorical question; pretended doubt; innuendo and insinuation; pretended error or ignorance; ambiguity; pretended attack on the victim's opponent; and stylistically signaled irony. Attardo (2000:84) argues that a "smallest possible disruption" of Grice's (1975) cooperative principle (CP) is put to work when irony is employed. Gibbs (1994) considers that the understanding of verbal irony requires the necessity of breaking Grice's truthfulness maxims and have a context of situation. How can readers infer writers' intentions when they attempt to produce irony? The solution is with reference to the violation to Grice's conversational maxims. The cooperative principle which accounts for Grice's (1975) "conversational implicature" is spelled out by four maxims, namely:

-quantity(a speaker should give the appropriate quantity of information);

-quality (information given should be correct or truthful);

-manner (expressions should be clear, non-ambiguous, brief and orderly); and

-relation (a speaker should maintain relevance to the subject matter and register).

"these maxims do not represent a descriptive statement of how conversational contributions are" (Coulthard 1985:31) and speakers or writers violate them often for a variety of purposes. When that happens, irony is likely to be employed.

\section{THE INTERPRETATION OF IRONY}

Grice's (1975) cooperative principle (CP) plays a crucial role in identifying irony encountered in literature. Take the following excerptions from THREE KINGDOMS for examples:

Example 1

权曰: “曹操部下战将, 还有多少? ”孔明曰: “足智多谋之士, 能征惯战之将, 何止一二千人。”权曰: “今曹 操平了荆、楚, 复有远图乎? ”孔明曰: “即今沿江下寨, 准备战船, 不欲图江东, 待取何地? ”权曰: “若彼有 吞并之意, 战与不战, 请足下为我一决。”孔明曰: “亮有一言, 但恐将军不肯听从。”权曰: “愿闻高论。”孔明 曰: “向者宇内大乱, 故将军起江东, 刘豫州收众汉南, 与曹操并争天下。今操败除大难, 略已平矣; 近又新破 荆州, 威震海内; 纵有英雄, 无用武之地: 故豫州遁逃至此。愿将军量力而处之: 若能以吴、越之众, 与中国 抗衡, 不如早与之绝; 若其不能, 何不从众谋士之论, 按兵束甲, 北面而事之? ”权未及答。孔明又曰: “将军 外托服从之名, 内怀疑氮之见, 事急而不断, 祸至无日矣! ”权曰: “诚如君言, 刘豫州何不降操? ”孔明曰: “昔

* This paper is sponsored by Education Ministry of China, the number of the project: (2006)7 
田横, 齐之壮士耳, 犹守义不辱。况刘豫州王室之贯, 英才盖世, 众士仰慕。事之不济, 此乃天也。又安能屈 处人下乎! ”("How many has he in all?" "Horse and foot, land and marine, he has a million." "Is there not some doubt about that?" said Sun Quan, surprised. "None whatever. When Cao Cao went to Yanzhou, he had the two hundred thousand soldiers of Qingzhou. He gained five or six hundred thousand more when Yuan Shao fell. He has three or four hundred thousand troops newly recruited in the capital. Lately he has acquired two or three hundred thousand troops in Jingzhou. And if these be reckoned up, the total is not less than a million and a half. Hence I said a million for I was afraid of frightening your officers." Lu Su was much disturbed and turned pale. He looked meaningfully at the bold speaker, but Zhuge Liang would not see. Sun Quan went on to ask if his archenemy had a corresponding number of leaders. "Cao Cao has enough administrators and strategists to control such a host, and his capable and veteran leaders are more than a thousand; perhaps more than two thousand." "What will be Cao Cao's next move now that he has overcome Jingzhou?" "He is camped along the river, and he has collected a fleet. If he does not intend to invade the South Land, what can his intentions be?" "Since that is his intention, it is a case of fight or not fight. I wish you would decide that for me." "I have something I could say, but I fear, Sir, you would not care to hear it." "I am desirous of hearing your most valuable opinion." "Strife has prevailed for a long time; and so you have raised your army in the South Land and Liu Bei collected his forces south of the Han River to act in contest for the empire against Cao Cao. Now Cao Cao has overcome most of his difficulties, and his recent conquest of Jingzhou has won him great and wide renown. Though there might be one bold enough to tackle him, yet there is no foothold for such. That is how Liu Bei has been forced to come here. But, General, I wish you to measure your forces and decide whether you can venture to meet Cao Cao and that without loss of time. If you cannot, then follow the advice of your councilors: Cease your military preparations and yield, turn your face to the north and serve." Sun Quan did not reply. But his guest went on, "You have the reputation of being reasonable, but I know also you are inclined to hesitate. Still this matter is most important, and evil will be quickly upon you if you do not decide." Then replied Sun Quan, "If what you say represents the actual conditions, why does not Liu Bei yield?" "Well, you know Tian Heng*, that hero of the state of Qi: His character was too noble for him to submit to any shame. It is necessary to remember that Liu Bei also is an off-shoot from the Dynastic Family, beside being a man of great renown. Everyone looks up to him. His lack of success is simply the will of Heaven, but manifestly he could not bow the knee to anyone." "Well, you know Tian Heng*, that hero of the state of Qi: His character was too noble for him to submit to any shame. It is necessary to remember that Liu Bei also is an off-shoot from the Dynastic Family, beside being a man of great renown. Everyone looks up to him. His lack of success is simply the will of Heaven, but manifestly he could not bow the knee to anyone."

*Tian Heng was a warrior of Qi at the end of the Warring States period and Qin Dynasty. In his bid to regain the lost kingdom of Qi, Tian Heng rebelled against Qin and fought both Liu Bang and Xiang Yu. Read Tian Heng Island. )

The underlined utterance 若其不能, 何不从众谋士之论, 按兵束甲，北面而事之? (If you cannot, then follow the advice of your councilors: Cease your military preparations and yield, turn your face to the north and serve.") is considered ironic. This utterance is considered a violation of the maxim of quality when in correlation with its context of situation, which is substantiated by the utterance below:

孔明曰: “昔田横, 齐之壮士耳, 犹守义不辱。况刘豫州王室之胃, 英才盖世, 众士仰慕。事之不济, 此乃天 也。又安能屈处人下乎! ”("Well, you know Tian Heng*, that hero of the state of Qi: His character was too noble for him to submit to any shame. It is necessary to remember that Liu Bei also is an off-shoot from the Dynastic Family, beside being a man of great renown. Everyone looks up to him. His lack of success is simply the will of Heaven, but manifestly he could not bow the knee to anyone." )

This clearly shows that maxim flouting strategy can serve as a trigger of irony. The real interpretation involves the truth-value resting in the reverse of what is said. That is to say, Zhuge Liang's ostensive meaning contradicts his intended one. The ironic device used here is to instigate Sun Quan's anti-CaoCao feelings.

Below is another example highlighting the importance of flouting conversational maxims in arriving at an ironic inference.

Example 2

至晚, 人报鲁子敬引孔明来拜。瑜出中门迎入。叙礼毕, 分宾主而坐。肃先问瑜曰: “今曹操驱众南侵, 和与 战二策, 主公不能决, 一听于将军。将军之意若何? ”瑜曰: “曹操以天子为名, 其师不可拒。且其势大, 未可 轻敌。战则必败, 降则易安。吾意已决。来日见主公, 便当遣使纳降。”鲁肃愕然曰: “君言差矣! 江东基业, 已历三世, 岂可一旦弃于他人? 伯符遗言, 外事付托将军。今正欲仗将军保全国家, 为泰山之靠, 奈何从懦夫 之议耶? ”瑜曰: “江东六郡, 生灵无限; 若罹兵革之祸, 必有归怨于我, 故决计请降耳。”肃曰: “不然。以将 军之英雄, 东吴之险固, 操未必便能得志也。”

二人互相争辩, 孔明只袖手冷笑。瑜曰: “先生何故哂笑？”孔明曰: “亮不笑别人，笑子敬不识时务耳。”肃 曰: “先生如何反笑我不识时务? ”孔明曰: “公瑾主意欲降操, 甚为合理。”瑜曰: “孔明乃识时务之士, 必与吾 有同心。”肃曰: “孔明，你也如何说此？”孔明曰: “操极善用兵，天下莫敢当。向只有吕布、袁绍、袁术、刘 表敢与对敌。今数人皆被操灭, 天下无人矣。独有刘豫州不识时务, 强与争衡; 今孤身江夏, 存亡未保。将军 决计降曹, 可以保妻子, 可以全富贵。国祚迁移, 付之天命, 何足惜哉! ”鲁肃大怒曰: “汝教吾主屈膝受辱于 国贼乎！” ....... 周瑜听罢, 勃然大怒, 离座指北而骂曰: “老贼欺吾太甚！”孔明急起止之曰: “昔单于屡侵疆 
界, 汉天子许以公主和亲, 今何惜民间二女乎? ”瑜曰: “公有所不知: 大乔是孙伯符将军主妇, 小乔乃瑜之妻 也。”孔明佯作惶恐之状, 曰: “亮实不知。失口乱言, 死罪！死罪！”瑜曰: “吾与老贼誓不两立！”孔明曰: “事 须三思, 免致后悔。”瑜曰: “吾承伯符寄托, 安有屈身降操之理? 适来所言, 故相试耳。吾自离鄱阳湖, 便有 北伐之心，虽刀斧加头，不易其志也！望孔明助一臂之力，同破曹贼。”孔明曰：“若蒙不弃，愿效犬马之劳， 早晚拱听驱策。”瑜曰: “来日入见主公, 便议起兵。” (About eventide Lu Su and Zhuge Liang came, and Zhou Yu went out to the main gate to receive them. When they had taken their proper seats, Lu Su spoke first, saying, "Cao Cao has come against the South Land with a huge army. Our master cannot decide whether to submit or give battle and waits for your decision. What is your opinion?" Zhou Yu replied, "We may not oppose Cao Cao when he acts at the command of the Emperor. Moreover, he is very strong, and to attack him is to take serious risks. In my opinion, opposition would mean defeat and, since submission means peace, I have decided to advise our lord to write and offer surrender." "But you are wrong!" stammered Lu Su. "This country has been under the same rule for three generations and cannot be suddenly abandoned to some other. Our late lord Sun Ce said that you were to be consulted on matters beyond the border, and we depended upon you to keep the country as secure and solid as the Taishan Mountains. Now you adopt the view of the weaklings and propose to yield! I cannot believe you mean it." Replied Zhou Yu, "The six territories contain countless people. If I am the means of bringing upon them the misery of war, they will hate me. So I have decided to advise submission." "But do you not realize our lord's might and the strength of our country? If Cao Cao does attack, it is very uncertain that he will realize his desire." The two wrangled for a long time, while Zhuge Liang sat smiling with folded arms. Presently Zhou Yu asked, "Why do you smile thus, Master?"

And Zhuge Liang replied, "I am smiling at no other than your opponent $\mathrm{Lu}$ Su, who knows nothing of the affairs of the day." "Master," said Lu Su, "what do you mean?" "Why, this intention to submit is perfectly reasonable. It is the one proper thing." "There!" exclaimed Zhou Yu. "Zhuge Liang knows the times perfectly well, and he agrees with me." "But, both of you, why do you say this?" said Lu Su. Said Zhuge Liang, "Cao Cao is an excellent commander, so good that no one dares oppose him. Only very few have ever attempted it, and they have been exterminated--the world knows them no more. The only exception is Liu Bei, who did not understand the conditions and vigorously contended against him, with the result that he is now at Jiangxia in a very parlous state. To submit is to secure the safety of wives and children, to be rich and honored. But the dignity of the country would be left to chance and fate--however, that is not worth consideration." Lu Su interrupted angrily, "Would you make our lord crook the knee to such a rebel as Cao Cao?" Zhou Yu listened to the end but then suddenly jumped up in a tremendous rage. Turning to the north and pointing with his finger, he cried, "You old rebel, this insult is too deep!" Zhuge Liang hastily rose too and soothed him, saying, "But remember the Khan of the Xiongnu People. The Han emperor gave him a princess of the family to wife although he had made many incursions into our territory. That was the price of peace. You surely would not grudge two more women from among the common people." "You do not know, Sir," replied Zhou Yu. "Of those two women of the Qiao family you mentioned, Elder Qiao is the widow of Sun Ce, our late ruler, and Younger Qiao is my wife!" Zhuge Liang feigned the greatest astonishment and said, "No indeed: I did not know. I blundered--a deadly fault--a deadly fault!" "One of us two has to go: Either the old rebel or I. We shall not both live. I swear that!" cried Zhou Yu. "However, such a matter needs a good deal of thought," replied Zhuge Liang. "We must not make any mistake." Zhou Yu replied, "I hold a sacred trust from my late lord, Sun Ce. I would not bow the knee to any such as Cao Cao. What I said just now was to see how you stood. I left Poyang Lake with the intention of attacking the north, and nothing can change that intention, not even the sword at my breast or the ax on my neck. But I trust you will lend an arm, and we will smite Cao Cao together." "Should I be happy enough not to be rejected, I would render such humble service as I could. Perhaps presently I might be able to offer a plan to oppose him." "I am going to see my lord tomorrow to discuss this matter," said Zhou Yu.)

There are five ironic devices in the above example:

1) 瑜曰: “曹操以天子为名, 其师不可拒。且其势大, 未可轻敌。战则必败, 降则易安。吾意已决。来日见 主公, 便当遣使纳降。” (Zhou Yu replied, "We may not oppose Cao Cao when he acts at the command of the Emperor. Moreover, he is very strong, and to attack him is to take serious risks. In my opinion, opposition would mean defeat and, since submission means peace, I have decided to advise our lord to write and offer surrender." ) It is considered ironic given its context of situation, which is substantiated by the utterance below:

瑜曰: “吾承伯符寄托, 安有屈身降操之理? 适来所言, 故相试耳。吾自离鄱阳湖, 便有北伐之心, 虽刀斧加 头, 不易其志也! 望孔明助一臂之力, 同破曹贼。” (Zhou Yu replied, "I hold a sacred trust from my late lord, Sun Ce. I would not bow the knee to any such as Cao Cao. What I said just now was to see how you stood. I left Poyang Lake with the intention of attacking the north, and nothing can change that intention, not even the sword at my breast or the ax on my neck. But I trust you will lend an arm, and we will smite Cao Cao together.")

This device gives rise to the violation of the maxim of quality because Zhou Yu's information given is contradicting his true intention. The ironic device used here is, to quote Zhou Yu's own words : “适来所言, 故相试耳” (What I said just now was to see how you stood.)

2) 孔明曰: “亮不笑别人, 笑子敬不识时务耳。”(Zhuge Liang replied, "I am smiling at no other than your opponent $\mathrm{Lu} \mathrm{Su}$, who knows nothing of the affairs of the day." )

According to the context of situation, this utterance features a blame in order to praise, realized by the violation of the maxim of quality. 
3) 孔明曰: “公瑾主意欲降操, 甚为合理("Why, this intention to submit is perfectly reasonable. It is the one proper thing.")This utterance features a praise in order to blame, realized by the violation of the maxim of quality.

4) 孔明曰: “独有刘豫州不识时务, 强与争衡......”(The only exception is Liu Bei, who did not understand the conditions and vigorously contended against him,) This utterance features a blame in order to praise, realized by the violation of the maxim of quality.

5) 孔明曰: “将军决计降曹, 可以保妻子, 可以全富贵。国祚迁移, 付之天命, 何足惜哉! ”(To submit is to secure the safety of wives and children, to be rich and honored. But the dignity of the country would be left to chance and fate---however, that is not worth consideration.) The much information about the benefit of submitting to CaoCao the underlined utterance is expressing infers a violation to the maxim of quantity. Moreover, the verbalization of the fate of DONG WU STATE is also a violation to the maxim of manner. Finally, given Zhuge Liang's real intention which is revealed throughout the whole passage, especially proved by the following:

瑜曰: “望孔明助一臂之力, 同破曹贼。”孔明曰: “若蒙不弃, 愿效犬马之劳, 早晚拱听驱策。”("Should I be happy enough not to be rejected, I would render such humble service as I could. Perhaps presently I might be able to offer a plan to oppose him."), this underlined utterance is violating the maxim of quality as well.

More examples of irony highlighting the importance of flouting conversational maxims can be identified.

Example 3

干葛巾布袍，驾一只小舟，径到 周瑜寨中，命传报：“故人蒋干相访。”周瑜正在帐中议事，闻将干至，笑 谓诸将曰: “说客至矣! ”遂与众将附耳低言, 如此如此。众皆应命而去。瑜整衣冠, 引从者数百, 皆锦衣花帽, 前后簇拥而出。蒋干引一青衣小童, 昂然而来。瑜拜迎之。干曰: “公瑾别来无恙! ”瑜曰: “子翼良苦: 远涉江 湖, 为曹氏作说客耶? ”干愕然曰: “吾久别足下, 特来叙旧, 奈何疑我作说客也? ”瑜笑曰: “吾虽不及师旷之 聪, 闻弦歌而知雅意。”干曰: “足下待故人如此, 便请告退。”瑜笑而挽其臂曰: “吾但恐兄为曹氏作说客耳。 既无此心，何速去也？”遂同入帐。叙礼毕，坐定，即传令悉召江左英杰与子翼相见。须舆，文官武将，各穿锦 衣; 帐下偏禆将校, 都披银铠: 分两行而入。瑜都教相见毕, 就列于两傍而坐。大张䇥席, 奏军中得胜之乐, 轮换行酒。瑜告众官曰: “此吾同窗契友也。虽从江北到此，却不是曹家说客。公等勿疑。”遂解佩剑付太史慈 曰: “公可佩我剑作监酒: 今日宴饮, 但叙朋友交情; 如有提起曹操与东吴军旅之事者, 即斩之! ”太史慈应诺, 按剑坐于席上。蒋干惊愕, 不敢多言。周瑜曰: “吾自领军以来, 滴酒不饮; 今日见了故人, 又无疑忌, 当饮 一醉。”说罢, 大笑畅饮。座上觥筹交错。饮至半醋, 瑜携干手, 同步出帐外。左右军士, 皆全装惯带, 持戈执 戟而立。瑜曰: “吾之军士, 颇雄壮否? ”干曰: “真熊虎之士也, ”瑜又引干到帐后一望, 粮草堆如山积。瑜曰: “吾之粮草, 颇足备否? ”干曰: “兵精粮足, 名不虚传。”瑜佯醉大笑曰: “想 周瑜与子翼同学业时, 不曾望有 今日。”干曰: “以吾兄高才, 实不为过。”瑜执干手曰: “大丈夫处世, 遇知已之主, 外托君臣之义, 内结骨肉 之恩, 言必行, 计必从, 祸福共之。假使苏秦、张仪、陆贾、梛生复出, 口似悬河, 舌如利刃, 安能动我心哉! ” 言罢大笑。蒋干面如土色。(Clad in a simple white robe and seated in his little craft, the messenger reached Zhou Yu's camp and bade the guards say that an old friend Jiang Gan wished to see him. The commander was in his tent at a council when the message came, and he laughed as he said to those about him, "A persuader is coming." Then he whispered certain instructions in the ear of each one of them, and they went out to await his arrival. Zhou Yu received his friend in full ceremonial garb. A crowd of officers in rich silken robes were about him. The guest appeared, his sole attendant a lad dressed in a simple blue gown. Jiang Gan bore himself proudly as he advanced, and Zhou Yu made a low obeisance. "You have been well I hope since last we met," said Jiang Gan. "You have wandered far and suffered much in this task of emissary in Cao Cao's cause," said Zhou Yu. "I have not seen you for a very long time," said the envoy much taken aback, "and I came to visit you for the sake of old times. Why do you call me an emissary for the Cao Cao's cause?" "Though I am not so profound a musician as Shi Kuang* of old, yet I can comprehend the thought behind the music," replied Zhou Yu. "As you choose to treat your old friend like this, I think I will take my leave," said Jiang Gan. Zhou Yu laughed again, and taking Jiang Gan by the arm, said, "Well, I feared you might be coming on his behalf to try to persuade me. But if this is not your intention, you need not go away so hastily." So they two entered the tent. When they had exchanged salutes and were seated as friends, Zhou Yu bade them call his officers that he might introduce them. They soon appeared civil and military officials, all dressed in their best. The military officers were clad in glittering silver armor and the staff looked very imposing as they stood ranged in two lines. The visitor was introduced to them all. Presently a banquet was spread, and while they feasted, the musicians played songs of victory and the wine circulated merrily. Under the mellowing influence, Zhou Yu's reserve seemed to thaw and he said, "Jiang Gan is an old fellow student of mine, and we are pledged friends. Though he has arrived here from the north, he is no artful pleader so you need not be afraid of him." Then Zhou Yu took off the commanding sword which he wore as Commander-in-Chief and handed it to Taishi Ci, saying, "You take this and wear it for the day as master of the feast. This day we meet only as friends and speak only of friendship, and if anyone shall begin a discussion of the questions at issue between Cao Cao and the South Land, just slay him." Taishi Ci took the sword and seated himself in his place. Jiang Gan was not a little overcome, but he said no word. Zhou Yu said, "Since I assumed command, I have tasted no drop of wine; but today as an old friend is present and there is no reason to fear him, I am going to drink freely." So saying he quaffed a huge goblet and laughed loudly.The rhinoceros cups went swiftly round from guest to guest till all were half drunk. Then Zhou Yu, laying hold of the guest's hand, led him outside the tent. The guards who stood around all braced themselves 
up and seized their shinning weapons."Do you not think my soldiers a fine lot of fellows?" said Zhou Yu."Strong as bears and bold as tigers," replied Jiang Gan. Then Zhou Yu led him to the rear of the tent whence he saw the grain and forage piled up in mountainous heaps."Do you not think I have a fairly good store of grain and forage?" "Your troops are brave and your supplies ample: The empire's gossip is not baseless, indeed." Zhou Yu pretended to be quite intoxicated and went on, "When you and I were students together, we never looked forward to a day like this, did we?" "For a genius like you, it is nothing extraordinary," said the guest. Zhou Yu again seized his hand, and they sat down. "A man of the time, I have found a proper lord to serve. In his service, we rely upon the right feeling between minister and prince outside, and at home we are firm in the kindly feeling of relatives. He listens to my words and follows my plans. We share the same good or evil fortune. Even when the great old persuaders like Su Qin, Zhang Yi, Lu Jia, and Li Yiji lived again, even when their words poured forth like a rushing river, their tongues were as a sharp sword, it is impossible to move such as I am!" Zhou Yu burst into a loud laugh as he finished, and Jiang Gan's face had become clay-colored. Zhou Yu then led his guest back into the tent, and again they fell to drinking.)

The underlined utterance 瑜告众官曰: “此吾同窗契友也。虽从江北到此，却不是曹家说客。公等勿疑。”(Zhou Yu's reserve seemed to thaw and he said, "Jiang Gan is an old fellow student of mine, and we are pledged friends. Though he has arrived here from the north, he is no artful pleader so you need not be afraid of him.")is considered ironic given the context, substantiated by the utterance before this utterance:

周瑜正在帐中议事, 闻将干至, 笑谓诸将曰: “说客至矣!”(The commander was in his tent at a council when the message came, and he laughed as he said to those about him, "A persuader is coming.")

and by the utterances after this utterance:

(周瑜)遂解佩剑付太史慈曰: “公可佩我剑作监酒: 今日宴饮, 但叙朋友交情; 如有提起曹操与东吴军旅之事 者, 即斩之! ”("You take this and wear it for the day as master of the feast. This day we meet only as friends and speak only of friendship, and if anyone shall begin a discussion of the questions at issue between Cao Cao and the South Land, just slay him.")

瑜执干手曰: “大丈夫处世, 遇知己之主, 外托君臣之义, 内结骨肉之恩, 言必行, 计必从, 祸福共之。假使 苏秦、张仪、陆贾、丽生复出, 口似悬河, 舌如利刃, 安能动我心哉! ” ("A man of the time, I have found a proper lord to serve. In his service, we rely upon the right feeling between minister and prince outside, and at home we are firm in the kindly feeling of relatives. He listens to my words and follows my plans. We share the same good or evil fortune. Even when the great old persuaders like Su Qin, Zhang Yi, Lu Jia, and Li Yiji lived again, even when their words poured forth like a rushing river, their tongues were as a sharp sword, it is impossible to move such as I am!" )

Hence, this underlined utterance gives rise to the violation of the maxim of quality since the real intention rest in the reverse of what is said. That is to say, Zhou Yu uses the ironic device to instigate implicit doubt and the dismay of Jiang Gan.

\section{CONCLUSION}

The examples above support the idea of minimal ironic devices to build discourse. As Simpson puts it, irony functions as "the infrastructure and determinant of the discourse" (2004:83) and "text-internal elements as textual evidence for inferencing"(2004:66), the making of meaning of and construction of sense resort to "conflictual textual or contextual evidence or markers socially agreed upon"(Hutcheon, 1995:11), "the relevance of an ironical utterance invariably depends, at least in part, on the information it conveys about the speaker's attitude the opinion echoed."(Sperber \& Wilson, 1995:239), hence the understanding of verbal irony requires the necessity of breaking Grice's (1975) cooperative principle (CP).

To sum up, this paper highlights the indispensability of resorting to Grice's (1975) cooperative principle (CP) for the analysis of irony in the interpretation of utterances. The theory of CP take us beyond the words to a philosophical world where certain rules are set to infer the real meaning of what is being said in the analysis of irony. This emphasizes the need to develop a pragmatic competence of reception and interpretation of irony where conversational strategies based on Grice's cooperative principle are applicable.

\section{REFERENCES}

[1] Attardo, S. (2000). Irony as relevant inappropriateness. Journal of Pragmatics 32, PP 793-826.

[2] Booth, W.C. (1974). A rhetoric of irony. Chicago: Chicago University Press.

[3] Coulthard, M. (1985). An introduction to discourse analysis. London: Longman.

[4] Gibbs, R.W. (1994). The Poetics of Mind: Figurative Thought, Language and Understanding. New York: Cambridge University Press.

[5] Grice, P. H. (1975). Logic and Conversation. In: P. Cole and J. Morgan (eds.). Syntax and Semantics vol. 3: Speech Acts. pp.41 58. New York: Academic Press.

[6] Hutcheon, L. (1995). Irony's Edge: The Theory and Politics of Irony. London; New York: Routledge.

[7] Muecke, D.C. (1969). The compass of Irony. London: Methuen.

[8] Muecke, D. C. (1982). Irony and the Ironic. London: Methuen.

[9] Simpson. P. (2004). On the Discourse of Satire: Towards a Stylistic Model of Satiric Humour. Amsterdam/Philadelphia: John Benjamins. 
[10] Sperber, D. \& D. Wilson. (1995). Relevance: Communication and Cognition. Oxford, Blackwell.

Qin Yao was born in Zhenjiang, China in 1974. She is pursuing her PH.D. degree in translation from Shanghai International Studies University, China. She is currently a lecturer in the School of Foreign Languages, Jiangsu University, Jiangsu, China. Her research interests include translation and American literature. 